\title{
Aplikasi Model Matematika Predator dan Prey Terinfeksi dengan Kontrol Pestisida pada Penyebaran Hama Wereng Batang Cokelat di Kabupaten Bantul
}

\author{
Irham Taufiq, Denik Agustito \\ Program Studi Pendidikan Matematika, Fakultas Keguruan dan IImu Pendidikan, \\ Universitas Sarjanawiyata Tamansiswa, Jalan Batikan UH III/1043 Yogyakarta, Indonesia
}

Korespondensi; Irham Taufiq, email: irham.taufiq@ustjogja.ac.id; Denik Agustito, email:

denikagustito@yahoo.co.id

\begin{abstract}
Abstrak
Penelitian ini bertujuan membentuk model matematika yang menunjukan interaksi antara predator dan prey dengan kontrol pestisida. Interaksi antara predator dan prey rentan menggunakan fungsi respon Holling tipe II. Sedangkan Interaksi antara predator dan prey terinfeksi menggunakan fungsi respon Holling tipe I. Pertumbuhan predator dan prey menggunakan fungsi logistik. Dari Model tersebut diperoleh lima titik ekuilibrium. ketiga titik ekuilibrium tersebut dianalisis menggunakan metode linierisasi dan bersifat stabil asimtotik lokal. Selanjutnya, data diterapkan pada model tersebut dengan simulasi numerik menggunakan software Maple untuk memprediksikan dinamika populasi predator dan prey. Hasilnya pada waktu tertentu predator akan mati dan prey tetap hidup.
\end{abstract}

Kata Kunci: Kontrol pestisida; model predator-prey; simulasi numerik; titik ekuilibrium

\begin{abstract}
This research aimed to construct a mathematical model showed the interaction between predator and prey by control of the pest. The interaction between predator and susceptible prey followed functional response Holling type II. But interaction between predator and infected prey followed functional response Holling type I. The population growth both predators and prey were using the logistic function. There were five equilibrium points for this model. Three of them was linearization method analyzed and asymptotic stability. Then, data was applicated into this model by numerical simulation used software Maple to predict dynamical population both of them. The result was in certain time predator will be die and prey will be exist.
\end{abstract}

Keywords: Control of pest; predator-prey model; numerical simulation; equilibrium point

\section{Pendahuluan}

Lahan pertanian padi seluas lima hektare di Dusun Baros, Desa Tirtohargo, Kabupaten Bantul, Daerah Istimewa Yogyakarta, mengalami puso akibat serangan hama wereng batang cokelat yang muncul pada musim hujan pada tahun 2016. Lima hektare sawah yang gagal panen akibat hama wereng tersebut karena faktor kelembapan yang tinggi. Petani diperkirakan mengalami kerugian hingga ratusan juta rupiah karena biaya produksi yang dibutuhkan sejak tanam hingga panen rata-rata Rp 30 juta sampai Rp 35 juta per hektare. Sementara itu, berdasarkan rekapitulasi data serangan wereng batang cokelat di Bantul yang dihimpun Dinas Pertanian dan Kehutanan Bantul pada awal Februari, tanaman padi yang terserang wereng seluas 280 hektare dengan luas ancaman 40 hektare [2].

Hama ini secara langsung dapat merugikan tanaman padi dengan cara menghisap cairan pelepah daun dan cairan sel tanaman, sehingga tanaman padi menjadi kering dan tunasnya berkurang. Wereng dapat mentransfer virus yang mengakibatkan warna daun dan batang tanaman padi berubah menjadi kuning, cokelat jerami, dan akhirnya seluruh tanaman padi menjadi mengering seperti disiram air panas [5]. Dari uraian tersebut perlu ada usaha untuk menyelamatkan tanaman padi dari serangan hama wereng, yaitu dengan pengendalian laju pertumbuhan hama wereng. 
Menurut [6], salah satu upaya yang dilakukan para petani untuk mengendalikan hama wereng adalah pemberian pestisida. Penggunaan pestisida secara tidak tepat dapat menyebabkan berbagai dampak yang tidak diinginkan, seperti pencemaran lingkungan, hama menjadi tahan terhadap berbagai jenis pestisida, dan hama menjadi cepat menyesuaikan diri terhadap perubahan lingkungan [3]. Jika hanya menggunakan pestisida maka hama sulit untuk dikendalikan. Oleh karena itu perlu adanya cara pengendalian hama yang lain. Salah satu usaha untuk pengendalian hama, misalnya dengan menggunakan faktor predator/musuh alaminya [4].

Usaha pengendalian hama dengan menggunakan musuh alaminya cukup mudah. Hal ini didukung dengan ketersediaan populasi predator biasanya tetap terjaga saat populasi hama rendah dan pola pemangsaan serangga predator dapat memangsa satu atau lebih spesies [10]. Interaksi antara individu memiliki beberapa sifat, salah satunya adalah pemangsaan. Pemangsaan merupakan hubungan antara predator dengan mangsa dalam interaksi dua populasi. Contoh pemangsaan semacam ini adalah wereng batang padi coklat (Nilaparvata lugens Stl.) yang dimangsa oleh pemangsa alaminya, seperti kepik mirid (Cyrtorhinus lividipennis).

Model matematika, menjadi alat penting untuk mengetahui proses dinamika antara predator dan hama serta menganalisa penyebaran hama pada waktu tertentu. Model ini, terdiri dari laju perubahan populasi predator dan populasi hama sebagai mangsa, yang pertama kali dikemukakan oleh Lotka Volterra. Model Lotka-Volterra dapat dikembangkan untuk memodelkan interaksi antara predator dan satu prey. [1] telah menurunkan model dua predator dan satu prey dengan asumsi pertumbuhan predator dan prey mengikuti pertumbuhan logistik dan terjadi kompetisi antara kedua predator tersebut. Selain itu, [7] dan [8] juga telah menurunkan model predator prey dengan prey terinfeksi dengan kontrol pestisida.

Selanjutnya, model tersebut diaplikasikan pada populasi wereng batang cokelat yang menyerang kabupaten Bantul. Pada penelitian-penelitian tersebut, masalah model matematika predator dan prey terinfeksi dengan kontrol pestisida belum pernah diteliti oleh peneliti-peneliti lain. Oleh karena itu, Penulis tertarik untuk meneliti aplikasi model matematika predator dan prey terinfeksi dengan kontrol pestisida pada penyebaran hama wereng batang cokelat di kabupaten bantul.

\section{Landasan Teori}

\section{Sistem Persamaan Diferensial}

Diberikan himpunan terbuka $E \subseteq R^{n}$ dan $\quad \mathbf{f}: E \subseteq R^{n} \rightarrow R^{n}$ didefinisikan fungsi $\mathrm{f}=$ $\left(f_{1}(x), f_{2}(x), \ldots, f_{n}(x)\right)$. Sistem persamaan diferensial sebagai berikut:

$\dot{x}_{1}=f_{1}\left(x_{1}, x_{2}, \ldots, x_{n}\right)$

$\dot{x}_{2}=f_{2}\left(x_{1}, x_{2}, \ldots, x_{n}\right)$

$\vdots$

$\dot{x}_{n}=f_{n}\left(x_{1}, x_{2}, \ldots, x_{n}\right)$

Selanjutnya, diberikan kondisi awal $x_{i}\left(t_{0}\right)=x_{i 0}$ untuk $i=1,2, \ldots, n$ dan $\dot{x}_{i}=\frac{d x_{i}}{d t}$ Sistem (1) dibentuk menjadi

$\dot{\mathbf{x}}=\mathbf{f}(\mathbf{x})$

dengan $\mathbf{x}=\left(x_{1}, x_{2}, \ldots, x_{n}\right) \in R^{n}, \mathbf{f}=\left(f_{1}, f_{2}, \ldots, f_{n}\right), \dot{\mathbf{x}}=\left(\dot{x}_{1}, \dot{x}_{2}, \ldots, \dot{x}_{n}\right)$ dan syarat awal $\mathrm{x}\left(t_{0}\right)=\mathrm{x}_{0}=$ $\left(x_{10}, x_{20}, \ldots, x_{n 0}\right) \in E$. Selanjutnya, notasi $\mathrm{x}(t)=\mathrm{x}\left(\left(\mathrm{x}_{0}, t\right), t\right)$ menyatakan solusi Sistem (2.2.2) dengan nilai awal $\mathrm{x}_{0}$.

\section{Titik Ekuilibrium}

Titik ekuilibrium merupakan solusi khusus dari Sistem (2), jika solusi tersebut konstan sepanjang waktu. Berikut ini dijelaskan mengenai titik ekuilibrium Sistem (2) pada definisi di bawah ini.

Definisi 1. Titik $\hat{\mathbf{x}} \in R^{n}$ disebut titik ekuilibrium Sistem (2) jika $\mathrm{f}(\hat{\mathrm{x}})=0$.[9] 
Kestabilan titik ekuilibrium dari suatu sistem persamaan diferensial linier ataupun nonlinier diberikan dalam definisi. Definisi berikut memberikan penjelasan kestabilan lokal dari titik ekuilibrium Sistem (2).

Definisi 2. Titik ekuilibrium $\hat{\mathbf{x}} \in R^{n}$ dari Sistem (2) dikatakan:

1. Stabil jika untuk setiap $\varepsilon>0$ terdapat $\delta>0$ sedemikian hingga untuk setiap solusi $\mathrm{x}(t)$ yang memenuhi $\mathrm{x}\left(t_{0}\right)-\hat{\mathrm{x}} \|<\delta$ berlaku $\|\mathrm{x}(t)-\hat{\mathrm{x}}\|<\varepsilon$ untuk setiap $t \geq t_{0}$.

2. Stabil asimtotik lokal jika titik ekuilibrium stabil dan terdapat bilangan $\delta_{0}>0$ sedemikian hingga unntuk setiap solusi $\mathbf{x}(\mathrm{t})$ yang memenuhi $\mathrm{x}\left(t_{0}\right)-\hat{\mathrm{x}} \|<\delta_{0}$ berlaku $\lim _{t \rightarrow \infty} \mathrm{x}(t)=\hat{\mathrm{x}}$.

3. Tidak stabil jika titik ekuilibrium $\hat{\mathbf{x}} \in R^{n}$ tidak memenuhi (1). [9]

\section{Model Dasar Mangsa Pemangsa}

Model Lotka-Volterra adalah model mangsa pemangsa yang paling sederhana yang menggambarkan interaksi populasi pemangsa dan mangsa yang diberikan sebagai berikut:

$$
\begin{aligned}
& \frac{d X}{d t}=p X-\alpha^{*} X Y \\
& \frac{d Y}{d t}=-q Y+r \alpha^{*} X Y
\end{aligned}
$$

Pada Sistem (3), $X$ menyatakan kepadatan populasi mangsa sedangkan $\frac{d X}{d t}$ menyatakan perubahan kepadatan populasi mangsa terhadap $t$, dengan $t$ adalah waktu dan $Y$ menyatakan kepadatan populasi pemangsa, dan $\frac{d Y}{d t}$ menyatakan perubahan kepadatan populasi pemangsa terhadap waktu. Konstanta $p, \alpha^{*}, q, r$ bernilai positif dengan $p$ adalah tingkat pertumbuhan alami dari populasi mangsa, $\alpha^{*}$ adalah angka penangkapan mangsa oleh pemangsa atau angka kematian dari populasi mangsa akibat interaksi dengan pemangsa, $q$ adalah tingkat kematian alami dari pemangsa, dan $r$ adalah angka pertumbuhan dari populasi pemangsa. Selain itu, $X Y$ adalah lambang interaksi antara mangsa dan pemangsa.

\section{Fungsi Respon}

Fungsi respon adalah meningkatnya jumlah mangsa yang dimakan oleh sejumlah individu pemangsa pada kepadatan mangsa yang berbeda-beda sampai dengan batas yang dapat menunjukkan konsumsi mangsa maksimal dalam waktu yang ditentukan. Pada saat ini, model Lotka-Volterra pada Sistem (3) sudah tidak relevan dalam kehidupan nyata karena popolasi mangsa tidak selamanya meningkat, atau populasi pemangsa tidak selamanya menurun. Hal ini dikarenakan ada lima hal yang mempengaruhi pemangsaan oleh pemangsa yaitu kerapatan populasi mangsa, kerapatan populasi pemangsa, sifat mangsa yang memiliki reaksi yang sama dengan predator, jumlah dan kualitas makanan pengganti yang tersedia untuk pemangsa, dan sifat pemangsa seperti jenis makanan yang disukai dan efisien dalam menyerang.

Selain itu, fungsi respon dibagi menjadi tiga tipe umum, yaitu fungsi respon linier (tipe I), fungsi respon hiperbolik (tipe II), dan fungsi respon sigmoida (tipe III). Fungsi respon linier (tipe I) merupakan fungsi respon dimana laju pemangsaan pemangsa meningkat sebanding dengan kerapatan mangsa sampai mencapai tingkat kejenuhan. Jumlah mangsa tidak berubah saat pemangsa kenyang. Fungsi respon hiperbolik (tipe II) merupakan fungsi respon dimana laju pemangsaan secara progresif semakin menurun. Artinya pemangsaan seekor pemangsa yang meningkat seiring dengan meningkatnya ketersediaan mangsa namun pemangsaan semakin menurun pada saat mendekati kenyang. Tingkat pemangsaan oleh pemangsa dipengaruhi ketersediaan mangsa. Holling berpendapat jika kerapatan mangsa meningkat maka daya cari pemangsa akan menurun sehingga waktu yang diperlukan pemangsa untuk memangsa lebih lama. Laju pemangsaan adalah waktu yang diperlukan pemangsa untuk mengejar, menaklukan dan memakan setiap individu mangsa. Fungsi respon ini sangat umum dimiliki diantara pemangsa serangga seperti wereng batang coklat. 


\section{Fungsi Logistik}

Populasi mangsa tidak selamanya meningkat atau populasi pemangsa tidak selamanya menurun. Hal ini disebabkan area dan fasilitas hidup terbatas. Sehingga model Lotka-Volterra pada Sistem (3) kurang realistis karena populasi tidak selamanya naik. Parameter $p$ dipengaruhi oleh angka pertumbuhan tanpa pengaruh lingkungan, dinotasikan $r$, dan angka kematian populasi mangsa karena pengaruh lingkungan, dinotasikan $\frac{r}{K^{\prime}}$ dalam hubungan linier

$$
p=r-\frac{r}{K} X
$$

Sehingga persamaan pertama pada Sistem (3) diperoleh:

$$
\frac{d X}{d t}=r X\left(1-\frac{X}{K}\right)-\alpha^{*} X Y
$$

\section{Bahan dan Metode}

Penelitian diawali dengan mengumpulkan berbagai informasi yang terkait wereng batang cokelat dan musuh alaminya pada ekosistem tanaman padi di Kabupaten Bantul. Informasi yang diperlukan berupa fakta-fakta terkait dinamika Kepik predator dan hama wereng batang cokelat dengan kontrol pestisida. Asumsi-asumsi model digunakan dan disusun untuk memberikan informasi tambahan yang tidak diperoleh dari fakta-fakta di lapangan guna untuk membantu memudahkan analisis suatu sistem.

Bentuk persamaan matematika dari model tersebut, dirumuskan dengan memperhatikan diagram transfer yang mengambarkan dinamika predator, hama wereng, dan efek pestisida pada ekosistem tanaman padi. Model matematika yang dihasilkan berbentuk sistem persamaan diferensial. Analisis yang dilakukan terhadap sistem adalah penentuan eksistensi titik ekuilibrium, kariteria kestabilan titik ekuilibrium dan simulasi dengan data wereng dan musuh alaminya yang diperoleh dari Dinas Pertanian, Pangan, Kelautan dan Perikanan Kabupaten Bantul. Dalam simulasi ini, dilakukan dengan bantuan software MAPLE. Hasil simulasi berupa potret fase yang menggambarkan dinamika predator dan prey dengan kontrol pestisida.

\section{Hasil dan Pembahasan}

Interaksi antara pemangsa dan mangsa dapat dimodelkan secara matematis ke dalam model predator dan prey. Model predator prey dapat digunakan untuk memodelkan interaksi antara predator, prey rentan dan prey terinfeksi dengan asumsi pertumbuhan predator dan prey mengikuti pertumbuhan logistik. Model tersebut berupa sistem persamaan diferensial non linier yang dapat diselesaikan secara kualitatif dengan menentukan kesetabilan dari titik ekuilibriumnya. Selanjutnya, perilaku dinamik model predator prey dengan prey terinfeksi dapat diketahui melalui analisis kesetabilan titik ekuilibriumnya.

Berikut akan dibahas mengenai pembentukan model matematika predator dan prey terinfeksi dengan kontrol pestisida. Jumlah individu pada populasi prey rentan pada saat waktu $t$ dinotasikan dengan $X(t)$, jumlah individu pada populasi prey terinfeksi pada saat waktu $t$ dinotasikan dengan $I(t)$, jumlah individu pada populasi predator pada saat waktu $t$ dinotasikan dengan $Y(t)$.

Kemudian diasumsikan bahwa populasi predator dan populasi prey bersifat tertutup, artinya tidak ada predator dan prey yang melakukan migrasi. Model predator prey yang dikaji terdiri dari predator, prey rentan dan prey terinfeksi. Pertumbuhan predator dan prey mengikuti pertumbuhan logistik.

Selanjutnya, diasumsikan bahwa apabila tidak ada interaksi antara pemangsa dan mangsa, maka pertumbuhan mangsa mengikuti model logistik yaitu dengan adanya keterbatasan daya dukung lingkungan sebesar $K$ dan tingkat pertumbuhan intrinsik $r$ akibatnya mangsa akan bertambah dengan

laju $r X\left(1-\frac{X}{K}\right)$. Kemudian perpidndahan populasi dari $X$ ke $I$ mengurangi laju pertumbuhan $X$. hal ini dipengaruhi laju interaksi antara hama yang rentan dan terinfeksi dengan peluang transmisi hama 
terinfeksi ke hama yang rentan $\beta$ dan kepadatan populasi $X$ dengan hama terinfeksi menghasilkan persamaan $\beta X I$. Pemangsaan pemangsa pada kelas mangsa menggunakan respon Holling tipe II yaitu $g(x)$

Ketika terdapat interaksi antara predator dan mangsa sebesar $g_{1}(x)$, pertumbuhan mangsa akan berkurang sebesar $g_{1}(x) Y$ yang merupakan laju perkalian antara fungsi respon Holling tipe II dengan populasi pemangsa $Y$ yaitu $g_{1}(x)=\frac{\rho_{1} X}{a+X}$ dengan $\rho_{1}$ adalah tingkat pemangsaan oleh predator, sehingga $g_{1}(x) Y=\frac{\rho_{1} X Y}{(a+X)}$.

Banyaknya kematian $X$ diakibatkan oleh pestisida $u$ yaitu $u X$. Dengan demikian, laju perubahan jumlah prey rentan terhadap waktu dapat dinyatakan sebagai

$$
\frac{d X}{d t}=r X\left(1-\frac{X}{K}\right)-\beta X I-\frac{\rho_{1} X Y}{a+X}-u X
$$

Kelas prey terinfeksi, selama selang waktu $t$, laju perubahannya dipengaruhi oleh perpindahan populasi $X$ menjadi $I$, yaitu $\beta X I$. Banyaknya kematian alami $I$ yaitu $m I$ yang merupakan perkalian antara laju kematian alami hama $m$ dengan kepadatan hama terinfeksi $I$. kemudian banyaknya kematian I diakibatkan oleh pestisida u yaitu ul. Kemudian berkurangnya populasi hama yang terinfeksi akibat pemangsaan predator $Y$ pada kelas hama terinfeksi $I$ pada pemangsaan ini proses pemangsaan menggunakan respon holling tipe 1 yaitu $g_{1}(I) Y$ yang merupakan laju perkalian antara fungsi respon holling tipe 1 dengan kepadatan predator $Y$ dengan $g_{1}(I)=\mu_{1} I$. Dari uraian tersebut, diperoleh persamaan laju perubahan populasi hama kelas terinfeksi menjadi

$\frac{d I}{d t}=\beta X I-\mu_{1} I Y-(m+u) I$

Kemudian, apabila tidak ada hama maka terjadi penurunan populasi predator dengan tingkat kematian alami sebesar $\rho$ tetapi apabila terdapat hama rentan maka terjadi interaksi antara predator dan prey rentan sebesar $\frac{\gamma_{1} \rho_{1} X Y}{a+X}$. Sedangkan apabila terdapat hama rentan maka terjadi interaksi antara predator dan prey terinfeksi yaitu $\gamma_{2} \mu_{1} I Y$. Banyaknya kematian $Y$ diakibatkan oleh pestisida $u$ yaitu $u Y$. Dengan demikian, laju perubahan jumlah predator terhadap waktu dapat dinyatakan sebagai

$\frac{d Y}{d t}=\frac{\gamma_{1} \rho_{1} X Y}{a+X}-\gamma_{2} \mu_{1} I Y-(p+u) Y$

Berdasarkan Persamaan (6), (7), dan (8) diperoleh model matematika predator dan prey terinfeksi dengan kontrol pestisida yang berupa sistem persamaan diferensial non linier sebagai berikut:

$\frac{d X}{d t}=r X\left(1-\frac{X}{K}\right)-\beta X I-\frac{\rho_{1} X Y}{a+X}-u X$

$\frac{d I}{d t}=\beta X I-\mu_{1} I Y-(m+u) I$

$\frac{d Y}{d t}=\frac{\gamma_{1} \rho_{1} X Y}{a+X}-\gamma_{2} \mu_{1} I Y-(p+u) Y$

dengan syarat awal $X(0)=X_{0}, I(0)=I_{0}, Y(0)=Y_{0}$

Model matematika predator dan prey terinfeksi dengan kontrol pestisida berupa sistem persamaan diferensial nonlinier. Penyelesaian kualitatif Sistem (9) dengan cara melihat perilaku sistem di sekitar titik ekuilibrium. Titik ekuilibrium untuk model matematika predator dan prey terinfeksi dengan kontrol pestisida pada Sistem (9) diperoleh jika $\frac{d X}{d t}=0, \frac{d I}{d t}=0, \frac{d Y}{d t}=0$.

Jika $\frac{d X}{d t}=0$, maka

$$
r X\left(1-\frac{X}{K}\right)-\beta X I-\frac{\rho_{1} X Y}{a+X}-u X=0
$$




$$
X\left[r\left(1-\frac{X}{K}\right)-\beta I-\frac{\rho_{1} Y}{a+X}-u\right]=0
$$

diperoleh $X=0$

atau

$r\left(1-\frac{X}{K}\right)-\beta I-\frac{\rho_{1} Y}{a+X}-u=0$

Kemudian, jika $\frac{d I}{d t}=0$, maka

diperoleh $I=0$

$$
\begin{aligned}
& \beta X I-\mu_{1} I Y-(m+u) I=0 \\
& I\left[\beta X-\mu_{1} Y-(m+u)\right]=0
\end{aligned}
$$

atau

$\beta X-\mu_{1} Y-(m+u)=0$

Kemudian, jika $\frac{d Y}{d t}=0$, maka

$$
\begin{aligned}
& \frac{\gamma_{1} \rho_{1} X Y}{a+X}-\gamma_{2} \mu_{1} I Y-(p+u) Y=0 \\
& Y\left[\frac{\gamma_{1} \rho_{1} X}{a+X}-\gamma_{2} \mu_{1} I-(p+u)\right]=0
\end{aligned}
$$

diperoleh $Y=0$

atau

$\frac{\gamma_{1} \rho_{1} X}{a+X}-\gamma_{2} \mu_{1} I-(p+u)=0$

Berdasarkan uraian tersebut, dari Persamaan (10), (12), dan (14) diperoleh titik ekuilibrium yaitu $T E_{1}=(0,0,0)$. Kemudian dari Persamaan (11), (12), dan (14) diperoleh titik ekuilibrium $T E_{2}=$ $\left(X^{*}, 0,0\right)$. Kemudian Persamaan (12), dan (14) disubstitusikan ke Persamaan (11) yaitu

$r\left(1-\frac{X}{K}\right)-\beta I-\frac{\rho_{1} Y}{a+X}-u=0$

$r\left(1-\frac{X}{K}\right)-\beta(0)-\frac{\rho_{1}(0)}{a+X}-u=0$

$r\left(1-\frac{X}{K}\right)=u$

$\left(1-\frac{X}{K}\right)=\frac{u}{r}$

$1-\frac{u}{r}=\frac{X}{K}$

$X=K-\frac{K u}{r}$

$X=\frac{K r-K u}{r}$

Jadi, diperoleh. $T E_{2}=\left(\frac{K r-K u}{r}, 0,0\right)$

Selanjutnya, dari Persamaan (11), (13), dan (14) diperoleh titik ekuilibrium $T E_{3}=\left(X^{*}, I^{*}, 0\right)$. Persamaan (14) disubstitusikan ke Persamaan (11) dan (13) yaitu:

$r\left(1-\frac{X}{K}\right)-\beta I-\frac{\rho_{1}(0)}{a+X}-u=0$

$r\left(1-\frac{X}{K}\right)-\beta I-u=0$

dan

$\beta X-\mu_{1}(0)-(m+u)=0$

$\beta X=(m+u)$

$X=\frac{(m+u)}{\beta}$ 
Kemudian persamaan (17) disubstitusikan ke persamaan (16) yaitu:

$r\left(1-\frac{\frac{(m+u)}{\beta}}{K}\right)-\beta I-u=0$

$\beta I=r-\frac{(m+u) r}{\beta K}-u$

$I=\frac{r-\frac{(m+u) r}{\beta K}-u}{\beta}$

Jadi diperoleh $T E_{3}=\left(\frac{(m+u)}{\beta}, \frac{r-\frac{(m+u) r}{\beta K}-u}{\beta}, 0\right)$.

Selanjutnya, dari Persamaan (11), (12), dan (15) diperoleh titik ekuilibrium $T E_{4}=\left(X^{*}, 0, Y^{*}\right)$.

Kemudian, dari Persamaan (11), (13), dan (15) diperoleh titik ekuilibrium $T E_{5}=\left(X^{*}, I^{*}, Y^{*}\right)$.

Teorema 1. Jika $r<u$, maka titik ekuilibrium $T E_{1}=(0,0,0)$ bersifat stabil asimtotik lokal.

Teorema 2. Jika $u<r, \beta k r<r m+r u+\beta k u$ dan $\gamma_{1} \rho_{1} k r+(p+u) k u<(p+u)(r a+k r)+$ $\gamma_{1} \rho_{1} k u$ maka titik ekuilibrium $T E_{2}=\left(\frac{K r-K u}{r}, 0,0\right)$ bersifat stabil asimtotik lokal.

Teorema 3. Jika $f_{33}<0, f_{11}+f_{22}<0$, dan $f_{11} f_{22}-f_{12} f_{21}>0$ maka titik ekuilibrium $T E_{3}=$ $\left(\frac{(m+u)}{\beta}, \frac{r-\frac{(m+u) r}{\beta K}-u}{\beta}, 0\right)$. bersifat stabil asimtotik lokal, dengan $f_{11}=r-\frac{2 r X}{K}-\beta I-u, f_{12}=$ $-\beta X, f_{21}=\beta I, f_{22}=\beta X-(m+u)$, dan $f_{33}=\frac{\gamma_{1} \rho_{1} X}{a+X}-\gamma_{2} \mu_{1} I-(p+u)$

Simulasi model dilakukan dengan menggunakan Software Maple. Simulasi ini bertujuan untuk melengkapi hasil-hasil yang diperoleh secara analisis pada bab sebelumnya. Pada bagian ini dilakukan simulasi titik ekuilibrium untuk mengetahui perilaku dinamik penyelesaian Sistem (9) dalam jangka waktu yang lama di sekitar titik ekuilibrium tersebut. Dalam simulasi model matematika predator dan satu prey terinfeksi dengan kontrol pestisida ini digunakan wereng batang coklat sebagai prey, sedangkan kepik mirid sebagai predator. Simulasi model matematika predator prey ini pada Sistem (9) menggunakan nilai parameter berdasarkan data dari dinas pertanian, pangan, perikanan dan kelautan kabupaten Bantul, [1], [7], dan [11]. Adapun nilai-nilai parameter yang digunakan adalah:

$r=1, \quad K=10, m=0,1, \quad p=0,3, u=0,5, \quad \beta=0,7, \quad \rho_{1}=0,5, \quad \gamma_{1}=0,15 \quad \gamma_{2}=0,2 \quad \mu_{1}=0,2$, $\mathrm{X}(0)=4, \mathrm{I}(0)=3$, dan $\mathrm{Y}(0)=3$

Apabila nilai parameter tersebut disubstitusikan ke model tersebut, maka diperoleh gambar berikut.

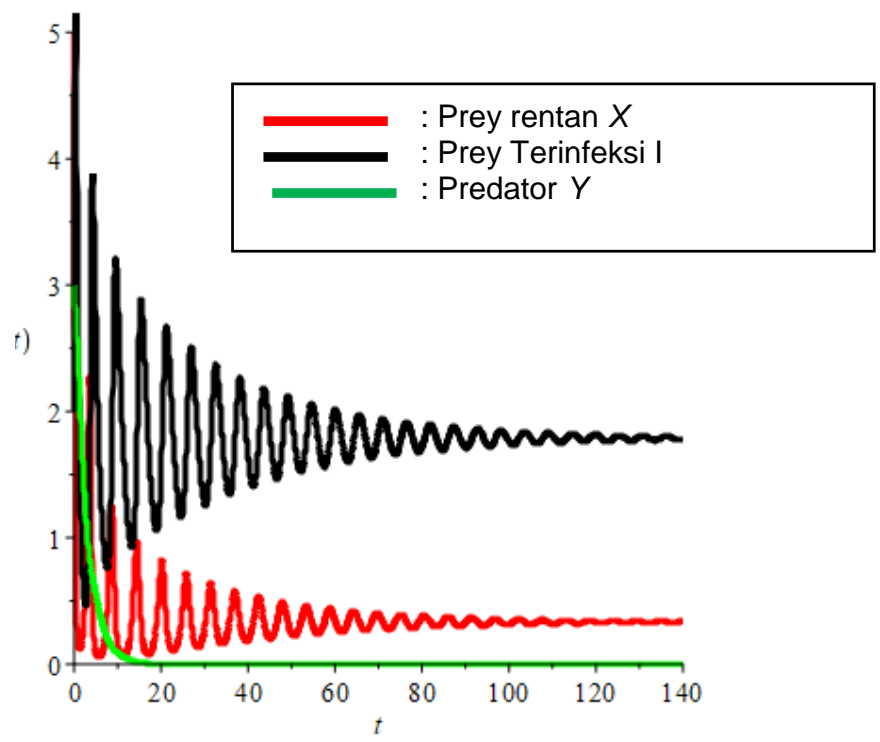

Gambar 1. Deret waktu dari perilaku Sistem (4) menggunakan data. 
Pada Gambar 1 diberikan nilai awal, terlihat pada waktu t tertentu bahwa solusi konvergen ke TE3. Dalam artian ketika diberikan nilai awal, pada waktu awal populasi mangsa rentan dan terinfeksi turun kemudian naik sedikit menuju nilai tertentu dan populasi predator turun sampai mendekati punah.

\section{Kesimpulan}

Dalam penelitian ini diberikan model matematika predator dan prey terinfeksi dengan kontrol pestisida. Sistem (9) memiliki delapan titik ekuilibrium. Kestabilan titik ekuilibrium Sistem (9) dianalisis hanya kestabilan lokal dengan metode linierisasi. Jika tingkat pertumbuhan intrinsik hama kurang dari tingkat kematian akibat pemberian pestsida maka predator dan prey akan punah dan bersifat stabil asimtotik lokal. tingkat pertumbuhan intrinsik hama lebih dari tingkat kematian akibat pemberian pestisida maka hanya hama rentan yang akan tetap hidup sedangkan yang lainnya akan punah dan bersifat stabil asimtotik lokal. Jika data dari dinas kabupaten bantul diterapkan pada model tersebut maka hasilnya pada waktu tertentu predator akan mati dan prey tetap hidup mengikuti TE3.

\section{Ucapan Terimakasih}

Penulis mengucapkan terima kasih kepada Dinas Pertanian Pangan Perikanan dan Kelautan Kabupaten Bantul yang telah membantu pengambilan data penelitian ini dan LP3M UST yang telah membiayai penelitian ini, serta semua pihak yang telah pberkontribusi pada penelitian ini.

\section{Referensi}

[1] Alebraheem, J dan Abu-Hasan, Y., 2012, Persistence of predators in a two predators-one prey model with non periodic solution, Applied Mathematical Sciences, Vol. 6, 2012, no. 19, 943956

[2] Antara. 2016. Wereng Pusokan Lima Hektare Sawah, diakses tanggal 18 februari 2018 dari https://www.republika.co.id/berita/nasional/daerah/16/02/17/o2ormp219-wereng-pusokan-lima-hektare-sawah-di-bantul

[3] Arif, A., 2015, Pengaruh Bahan Kimia Terhadap Penggunaan Pestisida Lingkungan, Jurnal Farmasi, UIN Alauddin 3(4)

[4] Baehaki SE, Mejaya, IMJ, dan Sembiring, H, 2013, Implementasi pengendalian hama terpadu dalam pengelolaan terpadu di indonesia. PENGEMBANGAN INOVASI PERTANIAN 6(4),198-209

[5] Baehaki, SE dan Mejaya, IMJ, 2014, Wereng Cokelat sebagai Hama Global Bernilai Ekonomi Tinggi dan Strategi Pengendaliannya. IPTEK TANAMAN PANGAN, 9(1), 112.

[6] Indiati, SW. dan Marwoto, 2017, Penerapan Pengendalian Hama Terpadu (PHT) pada Tanaman, 15(2):87-100

[7] Kar,T.K., Ghorai. A., and Jana, S.W., 2012, Dynamics of Pest and its Predator Model with Disease in the Pest and Optimal Use of Pesticide, Fever Epidemic Through the use, American Journal of Theoretical Biology 310: 187-198.

[8] Karim, IA., 2018, dinamika model predator hama wereng batang cokelat (nilaparvata lugens) pada tanaman padi dengan penerapan pestisida. Faktor Exacta 11 (1): 94-102

[9] Olsder, G. J., 1994, Mathematical Systems Theory, Delftse Uitgevers Maatschappij CW Delft, Netherland.

[10] Sianipar, MS, 2015, Populasi Hama Wereng Batang Coklat (Nilaparvata Lugens Stal.) Dan Keragaman Serangga Predatornya Pada Padi Sawah Lahan Dataran Tinggi Di Desa Panyocokan, Kecamatan Ciwidey, Kabupaten Bandung, Jurnal Agrikultura Unpad 26(2):111-121

[11] Sinha, S., Isra, O. P., dan Dhar, J., Modelling a predator-prey system with infected prey in polluted environment, Elsevier Inc, 2010, 1861-1872. 